\title{
Cohabitation Among University Students in Oyo State, South West Nigeria; Causes and Consequences: Implications for Counselling
}

\author{
Anna Onoyase ${ }^{1}$ \\ ${ }^{1}$ Department of Guidance and Counselling, Delta State University, Abraka, Delta State, Nigeria \\ Correspondence: Anna Onoyase, Department of Guidance and Counselling, Delta State University, P.M.B. 1, \\ Abraka, Delta State, Nigeria. E-mail: tinaonoyase@gmail.com
}

\author{
Received: January 12, 2020 Accepted: February 18, 2020 Online Published: February 25, 2020 \\ doi:10.5539/jel.v9n2p140 URL: https://doi.org/10.5539/jel.v9n2p140
}

\begin{abstract}
The investigator embarked on the research to find out the causes and consequences of cohabitation among university students in Oyo State, South-West Nigeria. In order to carry out the investigation, the researcher formulated two research questions and one hypothesis to guide the investigation. The researcher constructed an instrument known as "Cohabitation Among University Students, Causes and Consequences Questionnaire" (CAUSCCQ) to collect information from the respondents. The investigator carried out a reliability test of the instrument using the test re-test method. A reliability coefficient of 0.85 was obtained showing that the instrument was reliable to carry out the research. The items of the instrument had face and content validity as well as language appropriateness. The researcher used 3 research assistants to administer 271 copies of the instrument on the respondents. The research assistants retrieved 245 copies of the questionnaire. The researcher scored, collated and made use of the mean and standard deviation to answer the two research questions while one-way Analysis Of Variance ANOVA was used to test the hypothesis. The investigation revealed in Table 1 that some students cohabit because of high on-campus accommodation fee, with mean score of 2.79, some others cohabit due to financial difficulties in order to save on rent, food and other expenses and also as a result of their freedom from parental control and supervision. The research found out in Table 2 that one of the consequences of cohabitation is unwanted pregnancy with mean score of 3.52. The investigation also revealed in Table 2 that unwanted pregnancy may result into abortion with mean score of 3.49. Finally, the research found out that there is no significant difference among Federal, State and Private university student cohabiters in their assessment of the consequences of cohabitation. It is therefore recommended that Federal, State and Private owners of universities should put up adequate number of halls of residence for students.
\end{abstract}

Keywords: cohabitation, causes, consequences, federal, state and private universities

\section{Introduction}

It is no exaggeration that the number of students in Nigerian universities that is (Federal, State and Private) keep on increasing. The enrolment of students in Nigerian universities as given by Olufemi (2014, p. 140) shows that federal universities has a total of 326,310, state universities 174,303 and private universities 32,523 undergraduates respectively. As a result of the economic crunch in Nigeria at present, many of the universities lack the capacity to build students hall of residence. Lack of sufficient hall of residence may probably have led to emergence of cohabitation among university students. Adeniyi $(2019$, p. 11) maintained that cohabitation is when two people who are romantically involved choose to live together without making a formal commitment of marriage. Cohabiting couples are typically emotionally and sexually intimate. Adeniyi stressed that the term 'cohabitation' is not commonly used to describe people who are merely sharing a living space or who call themselves "roommates" cohabitation can pertain to either heterosexual or same sex couples, but it is most commonly used in reference to heterosexual couples. Abullahi (2013) stated that cohabitation can be encapsulated as both a status and a process and it is also an alternative type of housing for at least one of the cohabiters.

\section{Causes}

There are a number of probable reasons for cohabitation among university students and they include: 


\subsection{Higher Tuition Fees and Other Associated Costs}

As far as Pollard (2008), is concerned students in higher educational institutions are experiencing a critical situation in terms of higher tuition fees and other associated college costs related to facilities and services provision, especially on campus accommodation. Aluko (2009), stated that students in higher educational institutions are experiencing a crunch of spiral college costs hence, they have to take to cohabitation. Schoen (2009), stated that human behavior is shaped and related to the attributes of physical environment. The environment determines the range of behavior that can occur in it. Therefore, the students' behavior is either positively or negatively influenced by the physical environment. The high costs of college fees have in some cases, forced students to cohabit.

\subsection{Shortage of On-Campus Accommodation}

Svodziwa and Kurete (2017, p. 11), explained that shortage of on-campus accommodation, make students to resort to renting off-campus residential buildings. This is common with the public tertiary institution students in Nigeria. Svodziwa and Kurete pointed out that as contained in the university of Ibadan students' Handbook, accommodation is only available albeit on "first come first serve" basis to students in the first and final year of study. Therefore, majority of students in the second to penultimate years of studies are forced to live off-campus in communities adjoining their institutions. Soboye (2013), stated that inability of tertiary institutions to manage the increasing population through the provision of adequate hostel accommodation, have led to cohabitation among tertiary students in some public institutions. Aluko (2011, p. 31), stated that, because the population of students continues to grow without corresponding growth in the number of halls of residence and other physical facilities, therefore, cohabitation becomes the order of the day among the students in higher institution of learning.

\subsection{To study Each Other for Marriage}

Ogunsola (2004), stated that one of the main goals of cohabitation is for students to carefully study each other if they really matched for marriage. Hence, cohabitation may and may not eventually result into marriage.

Therefore, the durability of cohabitation is dependent upon purpose and the experiences of the individual involved. Brien, Lee and Steven (2006, p. 37), opined that couples learn about the quality of their relationship during cohabitation and some of them decide not to go through with their marriage. Brien, Lee and Steve, stated that on the other hand, some couples who otherwise would not have married end up married partly because they cohabitated.

\subsection{Financial Distress}

Lichter (2006), observed that financial distress is one of the reasons why students of higher institutions cohabit. This was corroborated by Alo and Akinde (2010), when they stated that the students cohabit because of economic reasons. Adeniyi (2019, p. 13), equally opined that students of higher institutions cohabit as a way to save on rent, food and other living expenses.

\subsection{Sexual Gratification}

Alo and Akinde (2010), opined that students of higher institutions cohabit because of sexual gratification. Whitehead and Popenoe (2006), asserted that young men showed greater acceptability of cohabitation than young women because males often enjoy the gains of cohabitations in terms of sexual gratification and sharing of domestic duties and a host of others than their female colleagues. This is because males are believed to have high sense of esteem when it comes to sexual matter and household chores especially in Africa (and in Nigeria to be specific) which have cultural abhorrence for premarital sex but demonstrate a double standard blaming one gender for premarital sexual behavior. Nigerian society, according to Whitehead and Popenoe (2006), expects women to exercise self-control than men when it comes to sexual behavior.

\subsection{Abandonment of Valued African Culture}

One of the causes of cohabitation among students of higher education institutions may be because many of the youths today have abandoned the rich African culture that forbids a boy and a girl from having sexual relationship until they are legally married. Probably, this was why Adeoye, Ola and Aliu (2012), opined that the contemporary youths have abandoned valued African tradition for inglorious culture of premarital sexual activities.

Arisikwu (2013), noted that cohabitation is totally against the norms and values of African society, therefore, allowing young unmarried couple to live together especially where they do not have family affinity is often regarded as albatross. However, some students cohabit without the knowledge of their parents, and on the 
otherhand, some parents encourage their wards to cohabit because of inability of such parents to meet the basic needs of their children in the institution.

\subsection{Loss of Religious Inclination}

Boys and girls of higher education institutions who decided to cohabit and have sexual relationship seem to have lost their religious inclination. Studies indicate that those with religious affiliation are less likely to cohabit than those without religious affiliation (Katz, 2001; Stanley, Whitton, \& Markman, 2004). Gault-Sherman and Drapen (2012), equally observed that individual religiosity is positively associated with more traditional family attitudes and behavior. Gault-Sherman and Draper further stated that norms regarding family formation, behavior of individual are commonly shaped and reinforced by religious institutions. They noted that strong religious parents can affect their child's behavior through guidance and supervision. However, it appears that religious inclination is no longer an issue when the present youths want to satisfy their desire in terms of cohabiting.

\subsection{Freedom from Parental Supervision}

Ogunbamila (2013), stated that cohabitation is common among undergraduates because many of them are being free for the first time, hence, they tend to enjoy the freedom, independence and less monitoring by either their parents or guardians.

\section{Consequences}

It is not an exaggeration that cohabitation among university students in Nigeria, has eroded the level of morality among the youths. There are many consequences in a male and female cohabitation in the university. Probably, that is why Adeniyi (2019, p. 10), stated that high rate of abortion in tertiary institutions can be attributed to cohabitation. Some of the cohabiting female students often get pregnant and because they are not prepared for parenting, some of them take to abortion which exposes the female partners to the risk of death or damaged uterus. Adeniyi also stressed that it is common place to find both cohabitants battling with one sexually transited disease or the other. Those involved in cohabiting tend to indulge in vices including stealing, lying and cyber crimes in order to raise finances to keep the affairs going. Adeniyi equally pointed out that at times, the females are more often than not abused and molested by their partners or "would be husbands" when they quarrel leading to grave psychological trauma that could affect their health and education. Adeniyi asserted that most of the students who cohabit find it difficult to graduate and they make lower grades because there is not enough time to read. Majority often withdraw from school, while some spend longer time than necessary as a result of carryovers.

Arisukwa (2013), stated that most students that cohabit do not allow their parents to know about it. This therefore exposes the students to all forms of risk and harm as they continue to cohabit. Aluko (2009), stated that some of the problems of cohabiting are, sacrificing of the primary aim of being in school, unwanted pregnancy, use of oral contraceptives by female students and the danger inherent in such practices. Aluko (2011), further, stated that financial involvement can bring the cohabiters into serious conflict. Aluko pointed out that some of the consequences are unprotected sex and its attendant effects such as unwanted pregnancies and other sexually transmitted diseases.

Fareo and Moses (2018, p. 31), investigated cohabitation among students of tertiary institutions in Adamawa State Nigeria, and found out that many students cohabited due to financial constraints, desire for intimacy and sex on regular basis and lack of conducive hostel facilities. Some students cohabit in order to avoid the harsh rules and regulations guiding their stay in halls of residence. The researchers found out that the consequences of cohabitation include, the possibility of contacting sexually transmitted diseases, poor academic result, prostitution, prolonged years of studentship, involvement in abortion, death, depressing and suicidal attempt.

\section{Operational Definition of Terms}

Cohabitation: Refers to two persons, man and woman who have no blood relations but are living together and sharing marital life and yet not legally married.

Causes: In this investigation, causes refer to factors responsible for cohabitation among university students.

Consequences: Refer to negative outcome of cohabitation.

Federal Universities: Refer to universities established, funded and managed by the Federal government of Nigeria.

State Universities: These are universities founded, financed and managed by State governments in Nigeria.

Private Universities: Refer to universities established, funded and managed by the individuals or corporate 
bodies that own them in Nigeria.

\section{Statement of the Problem}

There appears to be high demand for university education in Nigeria. Probably, that was why Egwunyenga (2018, p. 23), opined that the number of higher education in Nigeria by 1932 has grown from 02 to over 123 Federal Universities. Olufemi $(2014$, p. 140), stated that the number of students in Federal universities was about 326,310 as compared to 55,000 in 1980 . It is expected that the increase in the number of students should be matched with increase in the number of hostels accommodation. When this expectation of providing adequate on-campus accommodation for students by Federal government, State governments and proprietors of private universities is not met, students take to off-campus accommodation where many of them indulge in cohabitation. The problem of this research put in a question form is: what are the causes and consequences of cohabitation among university students?

\section{Research Questions}

Two research questions were raised:

1) What are the causes of cohabitation among university students in Oyo State, South - West Nigeria?

2) What are the consequences of cohabitation among university students in Oyo State, South - West Nigeria??

\section{Hypothesis}

There is no significant difference among federal, state and private university students cohabiters in their assessment of the consequences of cohabitation.

\section{Research Method and Procedure}

The technique used for this investigation is causal comparative research. Egbule and Okobiah (2012, p. 32), stated that causal comparative research is often referred to as expost - facto and it involves the investigation of possible cause - effects relationship by observing the consequences of one phenomenon on the other. It is on the basis of cause - effects relationship, that the researcher set out to investigate "cohabitation among university students in Oyo State, South West, Nigeria, causes and consequences: implications for counselling". The instrument utilized by the researcher to collect data from the subjects is known as "Cohabitation Among University Students, Causes and Consequences Questionnaire" (CAUSCCQ). The instrument was made up of 20 items, 10 of them were on causes of cohabitation and the remaining 10 were on the consequences of cohabitation among university students. The subjects were to show whether they agreed or disagreed with each of the 20 items by ticking $(\sqrt{ })$ strongly agreed $(\mathrm{SA})=4$, agreed $(\mathrm{A})=3$, disagreed $(\mathrm{D})=2$ and Strongly Disagreed $(\mathrm{SD})=$ 1.

The researcher carried out a reliability test of the questionnaire; thirty copies of the questionnaire were administered on 30 cohabiters who were not part of the main investigation and after two weeks, it was administered on them again. The Pearson's Product Moment Correlation was used to determine the relationship between the first test and second test. A reliability coefficient of 0.85 was obtained for the questionnaire. The instrument had content and face validity.

The population of the research was made up of student cohabiters in Federal, State and Private Universities in Oyo State, South-West Nigeria. The investigator made use of purposive sampling method to select 271 subjects that participated in the investigation. The researcher used 3 research assistants to administer 271 copies of the questionnaire on the respondents and 245 of them were retrieved. The researcher got the data collected from the fieldwork scored, collated and used the mean and standard deviation to answer the research questions while one-way Analysis Of Variance ANOVA was used to test the hypothesis. The researcher used 2.50 as benchmark to find out whether respondents agreed on disagreed with each of the 20 items on the questionnaire. The hypothesis was tested at 0.05 level of significance. 


\section{Findings}

\section{RESEARCH QUESTION ONE: What are the causes of cohabitation among university students in Oyo} State?

Table 1. Mean score and standard deviation analysis on causes of cohabitation among university students

\begin{tabular}{|c|c|c|c|c|}
\hline $\mathbf{S} / \mathbf{N}$ & Causes of cohabitation among university students & Mean & SD & Decision \\
\hline 1 & Some students cohabit due to high tuition fees. & 2.75 & 1.01 & Agreed \\
\hline 2 & High on-campus accommodation fees may be a reason for cohabitation among students. & 2.79 & 0.92 & Agreed \\
\hline 3 & $\begin{array}{l}\text { Shortage of on campus accommodation could make some students resort to stay off } \\
\text { campus and thus indulge in cohabitation. }\end{array}$ & 2.60 & 1.03 & Agreed \\
\hline 4 & $\begin{array}{l}\text { Due to financial difficulties some university students cohabit in order to save on rent, } \\
\text { food and other expenses. }\end{array}$ & 3.31 & 0.80 & Agreed \\
\hline 5 & Undergraduates may take to cohabitation for sexual gratification. & 2.97 & 0.87 & Agreed \\
\hline 6 & $\begin{array}{l}\text { Some undergraduates indulge in cohabitation due to their total disregard for African } \\
\text { norms and values for and purity before marriage. }\end{array}$ & 2.80 & 0.94 & Agreed \\
\hline 7 & $\begin{array}{l}\text { Another reason why students cohabit in universities is to test how compatible they are } \\
\text { for marriage. }\end{array}$ & 2.46 & 0.95 & Disagreed \\
\hline 8 & $\begin{array}{l}\text { Students from homes with low religious inclination may easily embrace cohabitation in } \\
\text { Nigeria university. }\end{array}$ & 2.92 & 0.88 & Agreed \\
\hline 9 & $\begin{array}{l}\text { Cohabitation among some undergraduates may be due to their freedom from parental } \\
\text { control and supervision. }\end{array}$ & 3.13 & 0.83 & Agreed \\
\hline \multirow[t]{2}{*}{10} & Some students cohabit in order to avoid the rules and regulations of on-campus hostels. & 2.71 & 0.96 & Agreed \\
\hline & Average mean score & 2.84 & 0.92 & Agreed \\
\hline
\end{tabular}

The investigation has revealed that the respondents agreed to almost all the items on Table 1 except item 7 which says that one of the reasons why students cohabit in universities is to test how compatible they are for marriage. Respondents disagreed with this item because the mean score of 2.46 is less than the benchmark of 2.50 . The research found out that some students cohabit due to high tuition fees with mean score of 2.75 , high on-campus accommodation fees may be a reason for cohabitation among students with mean score 2.79, shortage of on-campus accommodation could make some students resort to stay off campus and indulge in cohabitation with mean score of 2.60. Other causes of cohabitation among university students as revealed by the research include, financial difficulties that some of them go through and therefore resort to cohabitation in order to save on rent, food and other expenses with mean score of 3.31, some of the university students cohabit for sexual gratification with mean score of 2.97, some university, students indulge in cohabitation due to their total disregard for African norms and values for and purity before marriage, with mean score of 2.80. The investigation found out that some university students from homes with low religious inclination may easily embrace cohabitation with mean score of 2.92, cohabitation among some university students may be due to their freedom from parental control and supervision with mean score of 3.13 and finally, some university students cohabit in order to avoid the rules and regulations of on campus hostels with mean score of 2.71. All of them and the average mean score of 2.84 on Table 1 were more than the benchmark of 2.50 .

\section{RESEARCH QUESTION TWO: What are the consequences of cohabitation among university students in} Oyo State?

Table 2. Mean scores and standard deviation analysis on consequences of cohabitation among university students in Oyo State

\begin{tabular}{lllll}
\hline S/N & Consequences of cohabitant among university students in Oyo State & Mean & SD & Decision \\
\hline 1 & Cohabitation has eroded the level of morality among youth. & 3.31 & 0.78 & Agreed \\
2 & Cohabitation may bring about unwanted pregnancy. & 3.52 & 0.66 & Agreed \\
3 & Unwanted pregnancy may result into abortion. & 3.49 & 0.70 & Agreed \\
4 & Abortion could lead to death if not properly handled. & 3.63 & 0.57 & Agreed \\
5 & Abortion could damage the female uterus. & 3.57 & 0.64 & Agreed \\
6 & Cohabitation may result into contacting sexually transmitted disease. & 3.45 & 0.69 & Agreed \\
7 & Some cohabiters may involve themselves in stealing and cybercrimes in order to raise money for & 3.16 & 0.81 & Agreed \\
& their upkeep. & & & \\
8 & Some cohabiters spend longer years in the university. & 2.86 & 0.94 & Agreed \\
9 & Some cohabiters drop-out of the university. & 2.92 & 0.94 & Agreed \\
10 & Some cohabiters graduate with lower grades. & 2.90 & 1.01 & Agreed \\
& Average mean score & 3.28 & 0.78 & Agreed \\
\hline
\end{tabular}


The research has revealed in Table 2 that respondents agreed to all the 10 consequences of cohabitation among university students since all the mean scores and average mean score were above the benchmark of 2.50 . For instance, cohabitation has eroded the level of morality among youths with mean score of 3.31, cohabitation may bring about unwanted pregnancy with mean score of 3.52, unwanted pregnancy may result into abortion with mean score of 3.49, abortion could lead to death if not properly handled, with mean score of 3.63, and abortion could damage the female uterus with mean score of 3.57. Others are, cohabitation may result into contacting sexually transmitted disease with mean score of 3.45 , some cohabiters may involve themselves in stealing and cybercrimes in order to raise money for their upkeep with mean score of 3.16, some cohabiters spend longer years in the university with mean score of 2.86 , some cohabiters drop-out of the university with mean score of 2.92 and some cohabiters graduate with lower grades, and mean score of 2.90 .

Hypothesis 1: There is no significant difference among federal, state and private university student cohabiters in their assessment of the consequences of cohabitation.

Table 3. Analysis of variance ANOVA of the difference among university student cohabiters in their assessment on consequences of cohabitation

\begin{tabular}{llllccc}
\hline Variables & Sum of squares & Df & Mean Square & F-cal & F-crit & Level of sign. \\
\hline Between groups & 54.047 & 2 & 27.024 & .027 & 19.430 & \\
With Groups & 6186.390 & 235 & 26.325 & & & 0.05 \\
Total & 6240.437 & 237 & & & & \\
\hline
\end{tabular}

The research in Table 3 has revealed that the value of F-calculated is .027 , F-critical is 19.430, degree of freedom is 2 and level of significance is 0.05 , since the value of F-critical 19.430 is greater than F-calculated of .027 at 2 degree of freedom and at 0.05 level of significance, the hypothesis which says, there is no significant difference among federal, state and private university student cohabiters in their assessment of the consequences of cohabitation is retained.

\section{Discussion}

One of the findings of the research is that some students cohabit due to high tuition fees with mean score of 2.75. This finding lays credence to Scheen (2009), when he stated that human behavior is shaped and related to the attributes of physical environment, he maintained that the environment determines the range of behavior that can occur in it, therefore, the student behavior is either positively or negatively influenced by the physical environment. The high costs of college fees have in some cases forced students to cohabit. The investigation revealed that shortage of on campus accommodation could make some students resort to stay off campus and thus indulge in cohabitation with mean score of 2.60. This finding agrees with Svodziwa et al. (2017), when they stressed that shortage of on-campus accommodation, make students to resort to renting off-campus residential building, and thus cohabit. The research found out in Table 1 that due to financial difficulties some university students cohabit in order to save on rent, food and other expenses. This finding gives credence to Adeniyi (2019), who opined that students of higher institutions cohabit as a way to save on rent, food and other living expenses. The research has found out that the reason why university students cohabit is not to test how compatible they are for marriage with mean score of 2.46 which is below the benchmark of 2.50. This finding contradicts Ogunsola (2004), who opined that one of the main goals of cohabitation is to carefully study each other if they really matched for marriage. The investigation has revealed that undergraduates may take to cohabitation for sexual gratification with mean score of 2.97 which is higher than the benchmark of 2.50. This finding supports Alo and Akinde (2010), who pointed out that some of the consequences are unprotected sex and its attendant effects such as unwanted pregnancies and other sexually transmitted diseases. Another consequence of cohabitation found out by the research is abortion by cohabiters with mean score of 3.49 which is above the benchmark of 2.50 in Table 2. This finding agrees with Adeniyi (2019), who noted that high rate of abortion in tertiary institutions can be attributed to cohabitation. According to Adeniyi, some of the cohabiting female students often get pregnant and because they are not prepared for parenting, some of them take to abortion which exposes the female partners to the risk of death or damaged uterus.

The research in Table 3 has revealed, that there is no significant difference among Federal, State and Private university student cohabiters in their assessment of the consequences of cohabitation. This finding has clearly shown that it does not matter the university which the student cohabiter belongs, whether federal, state or private university, they have all assessed the consequences of cohabitation of students the same way. 


\section{Conclusion}

The conclusion drawn by the researcher as a result of the findings is that, there is cohabitation among university students in Oyo State, South West, Nigeria. Some of the causes of cohabitation are, high tuition fees, high on-campus accommodation fees, shortage of on-campus accommodation and sexual gratification among undergraduates. Cohabitation may bring about unwanted pregnancy, may result into abortion and abortion could damage female uterus.

\section{Recommendations}

As a result of the findings and conclusion reached, the researcher proposed the following recommendations:

1) The Federal, State and Private owners of universities should put up adequate number of halls of residence for students.

2) The university authorities should charge moderate accommodation fees so that many students can afford it.

3) The rules and regulations in the halls of residence should not be so harsh so that students are encouraged to stay in them.

4) The State government should give scholarship to indigent students so that they can meet up with their financial obligations in the university (including payment for on-campus accommodation).

5) University Authorities should include issue of cohabitation in students' handbook; what constitutes cohabitation, its consequences on students and punitive measures to be meted out to students who indulge in it.

6) Parents should pay regular unscheduled visits to their children in universities so as to monitor their activities.

7) Unwanted pregnancy by cohabiters should not be aborted because abortion could lead to damage of female uterus and sometimes to death.

8) University Authorities should liaise with community leaders where students are cohabiting so as to put measures in place to regularly check students' hostels and sanction those found cohabiting.

\section{Counselling Implications}

The following are the counselling implications of this research:

1) Counsellors should liaise with medical personnel in health centres of their various universities to organize lectures on the health hazards of cohabitation (such as contacting sexually transmitted diseases, abortion and damage to female uterus) and effect of cohabitation on students' academics. For instance, prolonged years of study, drop-out and graduating with lower grades.

2) Counsellors are to collaborate with Students' Affairs' Officers of their universities to obtain students' home addresses to invite their parents for parents' conference on factors responsible for cohabitation among students (especially those that relate to parents), consequences of cohabitation on the students, their parents and the society at large.

\section{References}

Abullahi, M. (2013). Consequences of pre-marital sex among the youth, a study of university of Maiduguri. Journal of Humanities and Social Science, 10(1), 10-17. https://doi.org/10.9790/0837-01011017

Adeniyi, A. O. (2019). The effects cohabitation on academic performance of the students in tertiary institutions Nigeria. International Journal of Sociology and Anthropology Research, 5(2), 10-15.

Adeoye, A. O., Ola, O., \& Aliu, B. (2012). Prevalence of premarital sex and factors influencing it among students in private tertiary institutions in Nigeria. International Journal of Psychology and Counselling, 4(1), 6-9. https://doi.org/10.5897/IJPC11.030

Alo, O. A., \& Akinde, I. S. (2010). Premarital sexual activities in an urban society of south west, Nigeria. Retrieved on September 28, 2012 from http://wwwo.ea-formal.com

Aluko, O. (2011). The assessment of housing situation among students in the University of Lagos. African Research Review, 5(3), 109-118. https://doi.org/10.4314/afrrev.v5i3.67345

Aluko, O. (2009). Housing and urban development in Nigeria. Kins: Ibadan.

Arisikwu, O. C. (2013). Cohabitation among university of Ibadan undergraduate students. Research Journal on Humanities and Social Sciences, 3(5), 185-192.

Brien, M. J., Lee, A. I., \& Steven, S. (2006). Cohabitation, marriage and divorce in a model of match quality. 
International Economic Review, 47(2), 451-494. https://doi.org/10.1111/j.1468-2354.2006.00385.x

Egbule, J. F., \& Okobia, D. O. (2012). Research methods in education for colleges and universities. Agbor: Kmensuo Educational publishers.

Egwunyenga, E. J. (2018). Tending the Ivory Tower: Swimming against the tide 63rd in the series of Inaugural lectures of the Delta State University. Abraka, Nigeria.

Fareo, D. O., \& Moses, K. D. (2018). Cohabitation among students of tertiary institutions in Adamawa State, Nigeria. International Journal Education Research, 2(4), 31-42.

Gault, S. M., \& Draper, S. (2012). What will the neighbors think? The effects of moral communities on cohabitation. Review of Religious Research, 54(1), 45-67. https://doi.org/10.1007/s13644-011-0039-9

Katz, R. (2001). Effects of migration, ethnicity and religiosity on cohabitation. Journal of Comparative Family Studies, 32, 587-599. https://doi.org/10.3138/jcfs.32.4.587

Lichter, D. T. (2006). Marriage or dissolution? Union transition to marriage among, cohabiting women. Demography, 43, 223-240. https://doi.org/10.1353/dem.2006.0016

Manning, W. D., \& Smock, P. J. (2005). Measuring and modeling cohabitation, new perspectives from qualitative data. Journal of Marriage and the Family, 67, 989-1002. https://doi.org/10.1111/j.1741-3737.2005.00189.x

Ogunbamila, A. (2013). Demographic predictors of premarital sexual behavior among undergraduates. Nigerian Journal of Applied Behavioural Sciences, 1, 68-94.

Ogunsola, M. O. (2004). Premarital behavior and length of courtship as determinant of marital suitability among couples in Oyo, State Nigeria.Unpublished M.Ed Dissertation, University of Ibadan, Ibadan.

Olufemi, A. B. (2014). Funding universities and university education in Nigeria. In A. O. Julius, A. Sola \& B. S. Noel (Eds.), The National Universities Commission. Abuja, Yallam Press Ltd.

Pollard, T. (2008). Cohabitation a deadly trend in tertiary institutions at bursting point, a case study of the University of Ibadan. IFRA.

Schoen, R. (2009). Social background differences in early family behavour. Journal of Marriage and Family, 7(1), 384-395. https://doi.org/10.1111/j.1741-3737.2009.00606.x

Soboye, A. (2013). Factors that contribute to the prevalence and practice of cohabitation among Kenyatta, University Students Nairobi Kenya. A thesis submitted to the school of Environmental studies and human science, Kenyatta University for the award of degree of Master of science of family and consumer science.

Sovodziwa, G., \& Kurete, T. (2017). The psychigical consequences of cohabitation among students in Tai Solarin university of education, Ijagun Ogun State, Nigeria, O'zean. Journal of Applied Science, 6(2), 6570.

Stanley, S. M., Whitton, S. W., \& Markman, N. J. (2004). Maybe I do interpersonal commitment and premarital or non-marital cohabitation. Journal of family Issues, 25, 496-519. https://doi.org/10.1177/0192513X03257797

Whitehead, B., \& Popenoe, D. (2006). The state of our unions, the social health of marriage in America. Piscatoway NJ: National Marriage Project.

\section{Copyrights}

Copyright for this article is retained by the author, with first publication rights granted to the journal.

This is an open-access article distributed under the terms and conditions of the Creative Commons Attribution license (http://creativecommons.org/licenses/by/4.0/). 